Светозар Бошков

Универзитет у Новом Саду

Филозофски факултет

Одсек за историју

svetozarboskov@hotmail.com
Оригиналан научни рад

примљено: 1. март 2014

прихваћено: 1. октобар 2014

\title{
ПОГЛЕДИ РАСТИСЛАВА МАРИТА НА ВЕРОВАЊЕ И ОБИЧАЈЕ СТАНОВНИШТВА НА ТЕРИТОРИЈИ ПОДУНАВЉА У АНТИЧКО ДОБА *
}

Сажетак: У овом раду представљени су радови Растислава Марића о веровању и обичајима становништва на територији Подунавља у античко доба. Приказани су његови погледи и тумачења веровања и обичаја Трачана, Илира и Келта. Такође, су приказана и поједина божанства о којима имамо врло мало података и не можемо да утврдимо њихово право порекло. обичаји.

Кључне речи: Растислав Марић, Трачани, Илири, Келти, божанства, веровања,

Извори који говоре о веровању и обичајима становништва на територији Подунавља могу се поделити на писане и материјалне. У писане изворе спадају натписи и подаци античких аутора, а у материјалне рељефи са представама божанстава, геме и божанске статуе. На основу ових извора на територији Подунавља можемо сазнати нешто више о илирској, трачкој и келтској религији. Растислав Марић је врло рано почео да се бави овом тематиком, и његова докторска дисертација Антички култови у нашој земљи је незаобилазан приручник за све оне који се интересују за богове, обичаје, храмове и свештенике ових народа. Академик Драгослав Срејовић оцењује да су у овој студији Р. Марића закључци знатно поузданији од многи новијих „који се односе на култове локалних божанстава у време римске доминације“.

„Античко доба у нашој земљи непосредан је наставак преисторијског доба, те су и антички становници наше земље у неколико директни потомци преисторијског становништва“, каже Р. Марић. Он даље каже да се може „претпоставити да је њихова религија сачувала и елементе религије њихових

\footnotetext{
* Текст је настао као фазни резултат рада на пројекту Војвођански простор у контексту европске историје (број 177002) Министарства просвете, науке и технолошког развоја Републике Србије.

${ }^{1}$ D. Srejović, A. Cermanović-Kuzmanović, Leksikon religija i mitova drevne Evrope, Beograd 1992, 255.
} 
непосредних преисторијских предака, па да, према томе, познајући религију античких становника наше земље, можемо донекле упознати и религију њихових преисторијских претходника. Под античким култовима подразумевају се култови становника наше земље у предримско и римско доба““.

Р. Марић каже да се антички писци изгледа нису много интересовали за обичаје и веровања становника наше земље, али се ипак код Херодота, Скимна, Феста, Сервија, Флора и Амијана Марцелина могу наћи подаци о религији и култу Илира, Трачана и Келта, док ниједан антички писац не говори о религији становника наше земље у римско доба. ${ }^{3}$

$$
* * *
$$

Од трачких племена у нашој земљи по имену су познати Трибали и Мези. Из једног фрагмента атичког комедиографа Алексида сазнајемо да су Трибали имали обичај да онај што приноси жртву покаже званицама вечеру и мора сутра да (њима?) прода оно што им је изнео да виде, а да нису ни вечерали. ${ }^{4}$ На основу тога Р. Марић закључује да су Трибали, као уосталом и сви Индоевропљани, знали за обредне жртве. ${ }^{5}$

Из једног другог фрагмента сазнајемо о обичајима Меза. Посејдоније је записао да су се Мези из побожности уздржавали од једења живих створова, па због тога нису јели ни домаће животиње, а хранили су се медом, млеком и сиром, и живели спокојно. ${ }^{6}$ Д. Срејовић сматра да су то биле, како их он назива, секте чији су припадници водили строг аскетски живот, ${ }^{7}$ док Ф. Папазоглу сматра да се ово што пише Посејдоније односи само на мезијске свештенике, односно на један посебан слој, или сталеж, који се из верских разлога подвргао таквом режиму исхране, а не на све Мезе. ${ }^{8}$ Али, Р. Марић примећује да је тај Посејдонијев податак о Мезима у супротности са оним што налазимо код Флора (римског аутора из II века нове ере), где је забележено да су Мези „пре борбе с Красом принели својим боговима коња на жртву и заветовали се да ће, ако победе, принети на жртву дроб побијених непријатељских војсковођа и њиме се хранити“.9 ${ }^{9}$ Према томе изгледа да су Мези приносили и људске жртве, ${ }^{10}$ што би можда били трагови канибализма који су

${ }^{2}$ Р. Марић, Антички култови у нашој земљи, Београд 1933, 2.

${ }^{3}$ Исто, 3

${ }^{4}$ Alexidisfr. 241 (= Athen. XV, 671d).

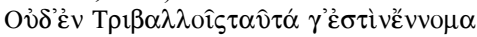

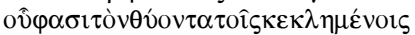

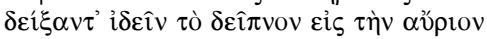

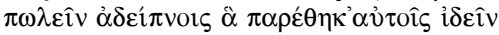

${ }^{5}$ Р. Марић, Антички култови у нашој земљи, 17; F. Papazoglu, Srednjobalkanska plemena u predrimsko doba (Tribali, Autarijati, Dardanci, Skordisci i Mezi), Sarajevo 1969, 379.

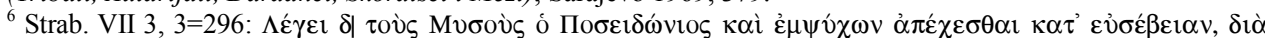

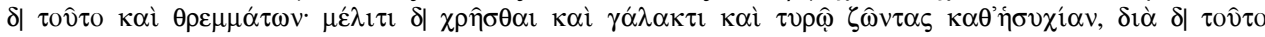

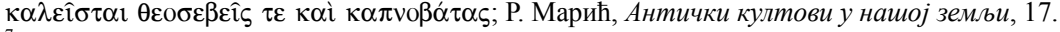

${ }^{7}$ Д. Срејовић, Илири и Трачани - о старобалканским племенима, Београд 2002, 303.

${ }^{8}$ F. Papazoglu, Nav. delo, 383.

${ }^{9}$ Р. Марић, Антички култови у нашој земьи, 17.

${ }^{10}$ Исто. 
присутни само у најзаосталијим племенима. ${ }^{11}$

Што се тиче трачких божанстава, на територији наше земље спомињу се Збелтурд, ${ }^{12}$ трачка Хера, трачки Јупитер, трачки Аполон и „Трачки коњаник“. Збелтурд је представљен као наг, брадати Зевс, који стоји спреман да баци муњу, док поред њега пузи змија, а на његовој левој руци стоји орао. Грчки Зевс се никад не

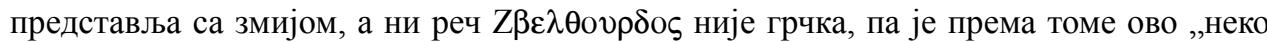
страно божанство идентификовано са Зевсом“. ${ }^{13}$ И Р. Марић и Д. Срејовић се слажу да би као врховно божанство Збелтурд био бог неба, ${ }^{14}$ али Р. Марић још каже да је сасвим вероватно да је Збелтурд могао бити и хтонско божанство. ${ }^{15}$ Алтернација $\lambda / \rho$ у његовом имену и разни облици имена на натписима показују да и не знамо како је у ствари гласило, закључује Р. Марић.

О трачкој Хери пише Полијен који каже да је Косингас, Херин свештеник и старешина трачких племена Кебрена и Сикабоја, једном приликом скупљао дрвене мердевине, стављао их једне на друге и спремао се да се попне на небо како би се пожалио Хери на Трачане због тога што га ови једном приликом нису послушали. Из тога се види да је нека трачка богиња идентификована са грчком Хером. На латинским натписима јавља се богиња Еракура (Aeracura) и Р. Марић сматра да би то могла да буде иста богиња, јер би ово име требало да буде латинска

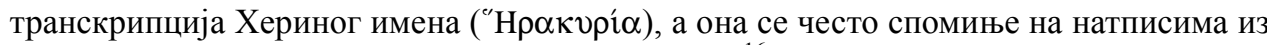
Тракије, па би према томе то била трачка богиња. ${ }^{16}$

Трачки Јупитер се појављује на једном натпису из Ниша као Iuppiter Optimus Maxsimus Aepilofius и Р. Марић каже да је Јупитер Епилофије трачко божанство неба, док се Трачки Аполон се појављује на неколико натписа и то као Аполон Таден, Аполон Етеуданик и Аполон Отеудон. ${ }^{17}$

О култу трачког коњаника доста се истраживало. Под тим именом се подразумевају представе на рељефима на којима је представљен коњаник огрнут хламидијом која лепрша. У десној руци има кратко копље, неку животињу или ју је подигао увис, а у левој држи узде, штит или лиру. На многим рељефима је испред коњаника дрво око кога се обавила змија, а поред коњаника трче пси и гоне неку дивљу животињу, најчешће дивљег вепра. Нису ретки случајеви да се поред коњаника налази једна, две или више жена. ${ }^{18}$ Оно што се са сигурношћу може рећи за трачког коњаника је то да је био распрострањен на великој територији од западних обала Црног мора до Поморавља и да се његова светилишта најчешће налазе под ведрим небом, покрај извора. ${ }^{19}$

Р. Марић каже да у нашој земљи није виђен ниједан храм трачког

\footnotetext{
${ }^{11}$ F. Papazoglu, Nav. delo, 384-385.

12 Д. Срејовић ово божанство назива Сбелсурд, Нав. дело, 303.

${ }^{13}$ Р. Марић, Антички култови у нашој земљи, 17.

${ }^{14}$ Р. Марић, Антички култови у нашој земљи, 19; Д. Срејовић, Нав. дело, 303.

${ }^{15}$ Р. Марић, Антички култови у нашој земљи, 19.

${ }^{16}$ Исто, 20-21.

${ }^{17}$ Итсо, 21-22.

${ }^{18}$ Исто, 22.

${ }^{19}$ Д. Срејовић, Нав. дело, 303; А. Цермановић-Кузмановић, Трачки коюаник (докторска дисертација).
} 
божанства, а могуће је да су њихова светилишта била на отвореном простору. ${ }^{20}$

Од келтских племена код нас једино о обичајима Скордиска имамо неких вести код античких аутора. Руфије Фест, Ливијев епитоматор, пише да су они некада својим боговима приносили на жртву ратне заробљенике и да су с уживањем пили крв из људских лобања, док Флор пише да нема ниједне врсте свирепости којом они нису искаљивали свој бес над заробљеницима и пише да су боговима жртвовали људску крв и да су пили из људских лобања. Да су Скордисци пили крв из испражњених људских лобања пишу и Амијан Марцелин и Орозије. ${ }^{21}$ Ф. Папазоглу наводи да је приношење људске жртве боговима имало за циљ да се њиховом проливеном крвљу ублажи њихова крволочна срџба, док су из утроба жртава врачи сазнавали вољу богова. ${ }^{22}$

По епиграфским изворима имена келтских богова на територији наше земље нема много. Спомињу се Матере (Matres, Matronae), Епона и нека божанства идентификована са Јупитером и Силваном. ${ }^{23}$ Матере су на рељефима увек представљене као три жене обучене у дуга одела и, понекад, с округлом капом на глави. Оне седе или стоје држећи у рукама корпе с плодовима или рогове изобиља и натписи који се налазе уз њих увек спомињу завете за здравље. Култ Епоне, богиње коња, био је раширен по целој територији где су живели Келти, а Р. Марићу је интересантна Епонина представа на дршци једне сребрне патере нађене на Руднику. Ту богиња седи на престолу држећи левом руком малог коња, а десном гранчицу. Поред ње стоји јарац и гледа ту гранчицу. ${ }^{24}$

Ни келтски храм није пронађен на територији наше земље. У Виминацијуму је нађено сребрно посуђе с натписом Matronae и Р. Марић каже да је можда припадало неком храму, али није познато где је он био. И на Руднику је пронађено сребрно посуђе, али са натписом Еропае. И оно вероватно потиче из неког Епониног храма, али није познато где се он налази. ${ }^{25}$

$$
* * *
$$

О илирским племенима има само један податак који је забележио ПсеудоСкимно који каже да су Илири били врло побожни и правдољубиви. Међутим, Р. Марић каже да се ове речи користе и у старинским етнографским причама када је реч „о здравим примитивним народима““. ${ }^{26}$

Нађен је један храм за који се са сигурношћу може утврдити да је био храм илирског божанства. То је Медаурова капела која је била поред Ескулаповог храма у Ламбези.

\footnotetext{
${ }^{20}$ Р. Марић, Антички култови у нашој земљи, 23.

${ }^{21}$ F. Papazoglu, Nav. delo, 385.

${ }^{22}$ Isto, 386.

${ }^{23}$ Р. Марић, Антички култови у нашој земљи, 25.

${ }^{24}$ Исто, 27-28.

${ }^{25}$ Исто, 29-30.

${ }^{26}$ Исто, 15.
} 
Ако нема писаних података о религији Илира, има много археолошких остатака. Д. Срејовић каже да се јасно уочавају разлике у духовној и материјалној култури између јужноилирских и северноилирских племена. Археолошки налази са јужних илирских територија указују на култ земље, док они са северних територија насељених Илирима упућују на астралне култове, првенствено на култ Сунца. ${ }^{27}$

На натписима су нам позната четири илирска божанства: Бинд Нептун, Медаур, Јупитер Партински и Андин. Бинд Нептун је божанство илирских Јапода. Лик Бинд Нептуна представљен је наг, корача налево и у левој руци држи неки нејасно представљен предмет, а у десној весло или трозубац. На представама се још појављује и јарац. На месту где је пронађен овај натпис налазило се много јарећих костију, што би могло да упућује да су ту били жртвовани јарци. Нептун нигде више нема епитет Биндус, а сама реч није ни латинска ни грчка, па према томе означава локално божанство идентификовано са Нептуном. ${ }^{28}$ Ову Марићеву тезу, да се ради о локалном божанству, који је повезан са поштовањем римског божанства Нептуна, прихватили су и други аутори попут Енвера Имамовића ${ }^{29}$ и Џона Вилкса (John Wilkes). ${ }^{30}$

За друго божанство за које се зна да је илирско сазнало се из једног натписа из Ламбезе, великог војног логора у северној Африци. На том месту пронађено је неколико вотивних натписа разним божанствима међу којима се налазио и један посвећен илирском божанству Медауру, богу заштитнику приморског града Ризинија, данашњег Рисна. ${ }^{31}$

За Јупитера Партинског Р. Марић каже да је био заштитник илирског града Парта, док о Андину знамо само то да је натпис са његовим именом пронађен на територији где су живели Дарданци. ${ }^{32}$

Од осталих домаћих божанстава за које није могуће одредити коме су племену припадала споменућу само Седата, јер Р. Марић каже да су вотивни натписи Седату ограничени на дунавске области и сасвим је могуће да је он био божанство неког племена које је живело у Подунављу, али се за њега не може са сигурношћу одредити да ли је келтско или илирско божанство. ${ }^{33}$

У време када је Растислав Марић писао о веровањима и обичајима домаћег становништва примећујемо да су тадашња сазнања о овој теми била врло оскудна. Ипак, на основу тих малобројних сачуваних историјских извора он је поставио основе о веровањима и обичајима домаћег становништва предримског доба. Сачувани фрагменти код античких аутора обавештавју нас само о неким обредним

\footnotetext{
${ }^{27}$ Д. Срејовић, Нав. дело, 303.

${ }_{28}$ Р. Марић, Антички култови у нашој земљи, 9-10; Р. Марић, Бинд, илирски бог извора, Годишњица Николе Чупића, књ. XLVIII, Београд 1939, 146-147.

${ }^{29}$ E. Imamović, Antički kultni i votivni spomenici na području Bosne i Hercegovine, Sarajevo 1977, 95.

${ }^{30}$ J. Wilkes, Iliri, Split 2001, 259.

${ }^{31}$ Р. Марић, Антички култови у нашој земљи, 10-11; Р. Марић, Ка Медауровом натпису из Ламбезе, Прилози за књижевност, језик, историју и фолклор, књ. 15, св. 1-2, Београд 1935, 203-204.

${ }_{32}$ Р. Антички култови у нашој земьи, 13.

${ }^{33}$ Исто, 31.
} 
радњама, али ништа поуздано на основу чега би се стекло бар неко сазнање о њиховој религији. На натписима се појављује мали број имена домаћих божанстава, али ако нема забележено име божанства, онда се, на основу рељефне представе, проналази одговарајуће грчко или римско божанство и на тај начин можемо да их упоредимо и одредимо функцију тог домаћег божанства. Врло је могуће да је домаће становништво имало много више божанстава него што ми знамо, али јак грчки и римски утицај на њихову религију условио је да сећања на та божанства заувек нестану.

\section{Литература:}

Imamović, Enver, Antički kultni i votivni spomenici na području Bosne i Hercegovine, Sarajevo 1977.

Марић, Растислав, Антички култови у нашој земљи, Београд 1933.

Марић, Растислав, Бинд, илирски бог извора, Годишњица Николе Чупића, књ. XLVIII, Београд 1939.

Марић, Растислав, Ка Медауровом натпису из Ламбезе, Прилози за књижевност, језик, историју и фолклор, књ. 15, св. 1-2, Београд 1935.

Papazoglu, Fanula, Srednjobalkanska plemena u predrimsko doba (Tribali, Autarijati, Dardanci, Skordisci i Mezi), Sarajevo 1969.

Srejović, Dragoslav, Cermanović-Kuzmanović, Aleksandrina, Leksikon religija i mitova drevne Evrope, Beograd 1992.

Срејовић, Драгослав, Илири и Трачани - о старобалканским племенима, Београд 2002.

Wilkes, John, Iliri, Split 2001. 


\title{
VIEWS OF RASTISLAV MARIĆ ON BELIEFS AND CUSTOMS OF THE POPULATION OF THE DANUBE REGION IN ANTIQUITY
}

\begin{abstract}
Summary
The paper presents the works of Rastislav Maric on beliefs and customs of the population on the territory around the Danube in antiquity. His views and interpretations of the beliefs of Thracians, Illyrians and Celts are presented. Furthermore, specific divinities on which we have very little data and cannot determine their true origin are also presented here.
\end{abstract}

Keywords: Rastislav Marić, Thracians, Illyrians, Celts, divinities, beliefs, customs. 